\title{
ARE CONSUMER HEALTH CONCERNS INFLUENCING DIRECT-FROM-PRODUCER PURCHASING DECISIONS?
}

\author{
SUDHA THAPALIYA \\ Department of Agricultural Economics, Mississippi State University, Mississippi State, Mississippi \\ MATTHEW G. INTERIS* \\ Department of Agricultural Economics, Mississippi State University, Mississippi State, Mississippi
}

ALBA J. COLLART

Department of Agricultural Economics, Mississippi State University, Mississippi State, Mississippi

LURLEEN M. WALTERS

Department of Agricultural Economics, Mississippi State University, Mississippi State, Mississippi

KIMBERLY L. MORGAN

Department of Agricultural and Applied Economics, Virginia Tech, Blacksburg, Virginia

\begin{abstract}
Research has shown health concerns may motivate consumers to purchase foods sold at direct market outlets, yet connections between management of specific diseases and food purchase decisions remain unclear. We utilize a two-step decision framework to evaluate whether family incidences of six illnesses (cancer, heart disease, diabetes, obesity, back/joint pain, and Alzheimer's disease/dementia) affect decisions to buy food at farmers' markets and farm stands. We find that cancer, diabetes, obesity, and back/joint pain influence the decision to purchase from farm stands. Disease incidences have varying directional effects on frequency of purchase for both farmers' markets and farm stands.
\end{abstract}

Keywords. Farmers' markets, farm stands, food purchases, health

JEL Classifications. D12, Q13

\section{Introduction}

Health motivations are a major driver of consumer food purchasing decisions (e.g., Chen et al., 2002; Food and Marketing Institute, 2013; Nayga, Lipinski, and Savur, 1998). Health motivation may be seen as a multidimensional system including the processes of choice, desire, and need for competency and

This research was funded by the U.S. Department of Agriculture Specialty Crop Block Grant Program and administered by the Mississippi Department of Agriculture and Commerce. We thank three anonymous reviewers for suggestions that helped improve the manuscript.

*Corresponding author's e-mail: m.interis@msstate.edu 
self-determinism regarding one's health (Cox, 1982). Consumers have become more conscious about health and nutrition over time (Darian and Tucci, 2011), and this increasing concern for health may be attributed to a rising prevalence of food-related chronic diseases such as diabetes, obesity, heart disease, cancer, and so forth (Darian and Tucci, 2011; McFadden and Low, 2012; Meyerhoefer and Leibtag, 2010). Maples et al. (2013) were among the first to examine the effect of family illness on the decision to purchase food directly from a producer. The authors found that presence of any illness they examined (cancer, heart disease, diabetes and obesity) in the respondent's family increased the likelihood of buying foods directly from producers; however, it was not possible to identify which of the specific diseases were driving the purchasing decision as they were aggregated into a single variable. Darian and Tucci (2011) found that high nutritional value and the potential to reduce the risk of cancer or heart disease play a vital role in consumers' purchase intentions. Similarly, Nayga, Lipinski, and Savur (1998) found that consumers, particularly those on special diets, placed importance on nutrition and on following dietary guidelines while shopping.

There is also evidence that purchases of food directly from the producer specifically are partially determined by health concerns (Govindasamy, Italia, and Liptak, 1997; Maples et al., 2013; Onozaka, Nurse, and McFadden, 2010; Schneider and Francis, 2005; Thilmany, Bond, and Bond, 2008; Wolf, Spittler, and Ahern, 2005; Zepeda and Li, 2006). The U.S. Centers for Disease Control and Prevention (CDC) specifically targets increased fruit and vegetable consumption as a way to combat obesity, and has supported incentive programs designed to encourage purchase of healthy foods at local outlets such as farmers' markets (Payne et al., 2013). Studies have also shown that the density of local food outlets such as farmers' markets and community-supported agriculture (e.g., Berning, 2012; Salois, 2012) or promotion of local food consumption (Conner and Levine, 2007; Thompson, Harper, and Kraus, 2008) are associated with positive health outcomes. Zepeda and Leviten-Reid (2004) find that people perceive that local foods have direct benefits to their personal health, although hard science is inconclusive about whether local food is indeed healthier than less local food (Martinez et al., 2010; Vogt and Kaiser, 2008).

Our study seeks to understand the impact of family disease incidence and of other health-related variables on purchases of food directly from a producer. We use online survey data of primary household food shoppers from six southeastern states. First, we evaluate how the occurrence of six particular illnesses (cancer, heart disease, diabetes, obesity, back or joint pain, and Alzheimer's disease or dementia) affects the decision to buy food at farmers' markets and farm stands. As opposed to allowing respondents to indicate a general health concern or perceived likelihood of contracting illnesses in the future as has been done in existing studies, we capture self-reported occurrences of specific diseases in the respondents or their family. Second, we elicit whether consumers follow a special diet for treating illnesses, fitness, or dietary preferences to examine how diet 
affects decisions to purchase food directly from a producer. Third, we elicit additional health-related variables that may affect food purchasing decisions, such as lifestyle changes for health reasons or food safety concerns and current levels of physical activity.

Our study seeks to address the current lack of understanding of precise health motivations that may drive consumers to spend additional time and resources to seek out and purchase food directly from producers. A particular focus is on whether, and how frequently, southeastern consumers buy foods at farmers' markets or farm stands, and we analyze these separate decisions in a two-step decision framework. Our findings add to the existing literature on factors influencing local food purchasing behavior as respondents were asked to report direct purchases from producers within the past 6 months. Findings from our study show different results for two markets. In the case of farm stands, most of the diseases have a positive and significant effect on the likelihood of food purchases. In the case of farmers' markets, this likelihood, although positive, is not statistically significant. Apart from diseases, most of the other health variables positively and significantly affect the likelihood and frequency of purchases in both markets.

\section{Data}

We used data from an online survey of consumers living in Alabama, Florida, Georgia, Louisiana, Mississippi, and Texas who had recently purchased foods from local food outlets such as farmers' markets and farm stands. The survey was administered by Research Now (based in Plano, TX), a large and well-known digital data collection company that has a large database of respondents who can be screened to reach a specific target audience. Potential respondents were screened to be over the age of 18 and to be the primary food shoppers in their households. In total, 4,707 respondents completed the survey ${ }^{1}$ in August 2013. Our sample was contrasted with respective state populations across demographic variables (Table 1) and determined to be fairly representative except that the sample is older than the population, likely because respondents were screened for adults who are primary food shoppers.

Respondents were asked to indicate whether they had bought any food at least once in the past 6 months at farmers' markets or farm stands and, if responding in the affirmative, the number of times they had made a purchase in the previous 30 days. Respondents were asked to indicate if they or any of their family members (spouse, siblings, father, mother, children, or grandparents) had been

1 Research Now asks members in its database to complete a survey until a given number of responses are collected. Because of the nature of this recruitment strategy, a standard response rate cannot be calculated, and neither would one be meaningful in the traditional sense because respondents have previously indicated their willingness to participate in surveys. 
Table 1. Survey Respondent Demographics Compared with 2010 U.S. Census Bureau Data by State

\begin{tabular}{llllll}
\hline \hline State & & Population & Percent Female & Percent White & Age (median years) \\
\hline Alabama & Sample & 301 & 56.8 & 75.08 & 52 \\
& State & 4.77 million & 51.5 & 68.5 & 37.9 \\
Florida & Sample & 1,061 & 52.87 & 77.19 & 50 \\
& State & 18.8 million & 51.5 & 75 & 40.7 \\
Georgia & Sample & 1,327 & 55.38 & 65.63 & 49 \\
& State & 9.68 million & 51.2 & 59.7 & 35.3 \\
Louisiana & Sample & 302 & 51.32 & 68.87 & 49.5 \\
& State & 4.53 million & 51 & 62.6 & 35.8 \\
Mississippi & Sample & 300 & 52.33 & 63.33 & 48 \\
& State & 2.96 million & 51.4 & 59.1 & 36 \\
Texas & Sample & 1,416 & 47.03 & 66.1 & 46.5 \\
& State & 25.14 million & 50.4 & 70.4 & 33.6 \\
\hline \hline
\end{tabular}

Source: U.S. Census Bureau (https://factfinder.census.gov/faces/nav/jsf/pages/searchresults.xhtml?refresh t).

treated for cancer, heart disease, diabetes, back or joint pain, Alzheimer's disease or dementia, or obesity. Respondents were asked whether someone in their household follows a special diet to treat illness or stay fit or because of dietary preference (vegan or vegetarian) or religious reasons and whether they had made any changes to their own lifestyle for health reasons. Respondents were asked to indicate their level of concern relative to their friends and family members on a five-point Likert scale about the safety of fresh produce items that are produced in the United States and in countries other than the United States and about whether they consider themselves to be less active (an equivalent of less than 1.5 miles of brisk walking daily), active (an equivalent of 1.5-3 miles of brisk walking daily), or more active (an equivalent of more than 3 miles of brisk walking daily).

In addition to health-related questions, respondents were asked to indicate the number of times they shopped for food per month at any outlet and the number of meals prepared at home per week. Respondents who grocery shop or cook more frequently are expected to purchase at local outlets such as farmers' markets and farm stands relatively more often. Because those who travel more frequently might be more likely to encounter local food outlets, respondents were asked to report the average number of days per month spent on travel for work or pleasure.

Seven true/false questions regarding U.S. fruit and vegetable production were asked to examine whether respondents' knowledge about agriculture increased consumer purchases at farmers' markets and farm stands. ${ }^{2}$ In addition, whether

2 The statements were as follows: One-half of all U.S. fruit acreage is located in California. Fresh fruit and vegetables grown in the southern United States are more susceptible to insect and plant diseases compared with northern or western production zones. For every \$1 U.S. consumers spend on fruits 
respondents were concerned about the price of food, the distance it travels from where it is produced to where it is sold, and the amount of pesticide residue on food was elicited.

Abello et al. (2014) found a negative effect of the distance to a farmers' market on consumer visits to such markets. To capture this effect, data from the U.S. Department of Agriculture, Agricultural Marketing Service (2014) were used to determine the number of farmers' markets within 5 miles of each respondent's zip code. Data on farm stands within 15 miles of respondent zip codes were identified on the LocalHarvest Inc. (2014) website. Finally, respondents were asked to indicate gender, age, education, race, whether U.S. or foreign born, number of people in the household, and family income.

\section{Conceptual and Empirical Model}

The impact of health-related variables on the decision to purchase food directly from the producer is presented as two separate decisions. The first decision is whether to buy food directly from growers at outlets such as farmers' markets or farm stands, and the second decision is how many times to purchase foods from those outlets for a given time period.

As for how local food purchases relate to disease incidence, we suppose the following: the principal food purchaser of a household considers many factors when deciding where to buy food and what type of food to buy. In particular, she may be concerned about managing an existing health issue of a household member (e.g., a son who is overweight for his age), or she may be concerned about preventing a health issue (e.g., her father has diabetes, so she believes she is at greater risk herself). We take as granted that food sold at farmers' markets and farm stands (e.g., generally produce, with meats and cheeses to a lesser extent) is generally offered in a fresh or minimally processed form (and contains little or no additives, preservatives, or artificial colorings). Much of this food is also sold at traditional outlets such as grocery stores, but perhaps there is a behavioral aspect ${ }^{3}$ in that by purchasing from a farmers' market or farm stand she knowingly intends to purchase relatively fresher food items directly from the producer. In any event, the food purchaser decides to purchase food from these

and vegetables, the U.S. farmer receives greater than one-third of that dollar. The 2011 Food Safety Modernization Act was established to provide a legislative mandate to require comprehensive, sciencebased preventative controls across the food supply. An acre of fresh tomatoes typically requires more water than is needed to provide an acre of wheat. Rinsing fresh fruits and vegetables with water removes all chemical and bacterial residues. All farmers' market managers are required to certify that their vendors sell only the fruits and vegetables grown on their own farm.

3 We do not directly model the possibility of this behavioral component but take it as an underlying assumption of the econometric model. Other assumptions that would lead to a similar relationship between health and local foods might be that the person believes it is a healthier choice to expend the effort needed to source and purchase food at outdoor markets or that the person lives in a food desert where fresh produce is not readily available. 
outlets in order to manage disease within her household or to prevent future disease in her household, with particular attention to diseases incurred by her extended family members (sibling, parents, and grandparents) to which she and her household might be more susceptible.

Given evidence of the linkages between diet and incidences of diseases (e.g., obesity) (U.S. Department of Health and Human Services [USDHHS], 2003), rising numbers of health-conscious consumers (Darian and Tucci, 2011), and consumer perceptions that locally produced foods may be healthier (Zepeda and Leviten-Reid, 2004), we expect respondents who report illnesses to be more likely to purchase directly from producers more frequently. ${ }^{4}$ Indeed, studies (e.g., World Health Organization, 2003, pp. 54-71) have shown that heart disease, diabetes, obesity, and cancer might be closely related to dietary decisions. We do allow for a possible caveat: if a given respondent does not tend to purchase healthy food, that may itself contribute to disease incidence. In other words, there is a possible endogeneity issue of disease incidence in the household, which we examine subsequently.

\subsection{Econometric Model}

Different modeling assumptions can be made about the relationship between the two decisions of whether and how often to purchase from local food outlets. Two common models that can be used for a discrete decision and a count decision are the Tobit model and the double-hurdle model (Gao, Wailes, and Cramer, 1995). A Tobit model assumes that the factors affecting whether to purchase from a farmers' market or farm stand have the same effect on how often to purchase from these outlets, whereas a double-hurdle model allows these effects to differ. To allow this flexibility, we adopt the double-hurdle model, which is a modified count data model that relaxes the assumption that the zero counts and positive counts come from the same data-generating processes (Cameron and Trivedi, 1998). If the number of counts is strictly positive, the first hurdle is crossed, and the conditional distance of the positives is governed by a truncated-at-zero count data model (McDowell, 2003). The second hurdle represents how often they buy given that they buy at least once. Hence, we specify a probit-Poisson double-hurdle model to account for both decisions.

A convenient feature of the probit-Poisson double-hurdle model is that the likelihood function can be separated across the two decisions with respect to the parameters to be estimated (McDowell, 2003). This allows estimation of the model in two separate steps: a binomial probit model for the first decision (step 1 ) and a truncated-at-zero count model for the second decision (step 2). Step 1

4 In the psychology literature (e.g., Vermeir and Verbeke, 2006), consumer behavior is often modeled as depending on perceived consumer effectiveness, which is a measure of how much the consumer believes a particular action (buying a product) will help address a problem (improve health). We did not elicit any such measures in our survey, however. 
consists of a probit model, and step 2 consists of a Poisson model conducted, without loss of information, only over observations for which the number of times a respondent purchases food from a local food source is strictly greater than zero (McDowell, 2003).

Using a random utility theory framework (McFadden, 1974), our model assumes for the first decision that a rational consumer buys from a local food outlet if and only if the utility she derives from buying there is greater than the utility derived from buying at another food outlet (e.g., grocery store). We assume that utility is linear in unknown parameters:

$$
u_{i c}=\mathbf{x}_{i}^{\prime} \boldsymbol{\beta}_{x c}+\varepsilon_{i c},
$$

where $u_{i c}$ is the utility of respondent $i$ from buying from a local food outlet $(c=1)$ or not $(c=0) ; \mathbf{x}_{\mathrm{i}}$ is a vector of characteristics of an individual $i$ including personal and family health history, other health-related variables, and other standard demographic variables; $\boldsymbol{\beta}_{x c}$ is a dimension-appropriate vector of parameters to be estimated; and $\varepsilon_{i c}$ is the random component of the utility.

Defining $u_{i}^{*}=u_{i 1}-u_{i 0}, \boldsymbol{\beta}_{x}^{*}=\boldsymbol{\beta}_{x 1}-\boldsymbol{\beta}_{x 0}$, and $\varepsilon_{i}^{*}=\varepsilon_{i 1}-\varepsilon_{i 0}$, we can then write:

$$
u_{i}^{*}=\mathbf{x}_{i}^{\prime} \boldsymbol{\beta}_{x}^{*}+\varepsilon_{i}^{*},
$$

where the parameter $\boldsymbol{\beta}_{x}^{*}$ can be estimated in a probit model (Greene, 2008).

A Poisson model, which is commonly used to model count decisions, is used to model the second decision of how many times to purchase from the market in a given time period. In our context, the Poisson model specifies the probability that a respondent visits a local food outlet $Y$ times in a given time period as follows:

$$
\operatorname{Pr}\left(y_{i}=Y\right)=\frac{\left(\mathbf{x}_{i}^{\prime} \boldsymbol{\alpha}_{x}^{*}\right)^{y_{i}}}{\left(\exp \left(\mathbf{x}_{i}^{\prime} \boldsymbol{\alpha}_{x}^{*}\right)-1\right) y_{i} !},
$$

where $y_{i}$ is the number of times individual $i$ purchases from a local food outlet. Both the probit and the Poisson models use maximum likelihood estimation.

\subsection{Analysis of the Family and a Test for Possible Endogeneity}

We chose to examine each of the six diseases separately in two family groups based on an assumption about which family members typically live in the same household and on the ideas of the family of orientation and the family of procreation from traditional marketing literature (Moore, Wilke, and Lutz, 2002; Palan and Wilkes, 1997). The family of orientation consists of parents and siblings, from whom a person acquires an orientation toward religion, politics, personal ambition, self-worth, and love. A more direct influence on everyday buying behavior is the family of procreation-the person's spouse and children. Therefore, our first group, the respondent's family of procreation, includes the respondent, her spouse, and children, and the second group includes the respondent's family of orientation (siblings, parents, and grandparents), who we assume are less likely to live with the respondent. In this way, we can examine 
how the effect of disease incidence on food purchases differs between when the disease is present within the household and when it is not. For example, respondents may purchase local foods as a preventative measure to protect their own household members from illnesses that have affected their other nonhousehold family members. On the other hand, respondents may purchase local foods as a reactive measure in order to treat or combat an illness incidence in their household. We must caution that this control is imperfect, however, as we did not directly ask which family members live in a respondent's household. Also, although we identify the respondent as the household's primary food shopper, that person may not be the exclusive decision maker of where and what to buy (Engel, Blackwell, and Miniard, 1990; Shepherd and Woodruff, 1988).

We used our assumption about the typical family members of a household to test for potential endogeneity of some explanatory variables. We hypothesize that disease incidences in the respondent's family affect whether she buys food at farmers' markets or farm stands, but the reverse-causal effect, that buying at those markets could affect disease incidences, is also possible. In particular, obesity is caused mainly by excess intake of unhealthy foods and inadequate exercise (USDHHS, 2003), and a feature of farmers' markets and farm stands is that they generally sell lower-calorie foods such as fresh fruits and vegetables. If obesity were thus endogenous, straightforward estimation of the model would then lead to biased parameter estimates (Greene, 2008). Although approaches such as a two-step instrumental variable probit model or Newey's (1987) minimum chi-squared estimator can be used to correct for an endogenous continuous regressor, we know of no test for endogeneity when the potentially endogenous variable is binary (obesity equals 1 if disease has occurred in respondent's family of procreation, and 0 otherwise). We therefore used two other approaches to check for endogeneity in the probit regression.

First, we specified a bivariate probit model where the second equation regresses the variable obesity on whether the respondent has obese parents or obese siblings, the output of which includes a correlation parameter between the two equations (Wooldridge, 2010). The validity of these instruments rests on our assumption that respondents, who are primary shoppers, generally do not live with their parents and siblings. If this assumption holds, then there could clearly be a correlation between the respondent having obese parents or siblings and there being an obese spouse or child, but it would be unlikely that the respondent would purchase local food to address obesity of a parent or sibling.

The results from the bivariate probit model are found to be almost identical to those from the binary probit model for both local food outlets (farmers' markets and farm stands). The correlation coefficient between the two equation error terms is -0.067 and not significant at the $10 \%$ level for farmers' markets and is -0.144 and not significant for farm stands. This gives us some indication that endogeneity of the obesity measure, as far as it may be caused by reverse causation, might not be a problem in our model. 
Another check for endogeneity is based on the idea of omitted variable bias. For this approach, we started with a simple model specification containing only the six diseases and demographic variables. We then sequentially added all the other regressors used in our final model presented herein with the idea being that the parameter estimate on an endogenous regressor would be more sensitive to the model specification. However, comparing across specifications, we found that the sign and significance of the obesity variable remained consistent. Observing no signals of likely endogeneity from either of these procedures, we proceeded under the assumption of exogeneity of the model explanatory variables.

\section{Results and Discussion}

Overall, slightly more than half of the respondents reported illness occurrences in their family; that is, $54 \%$ of the respondents indicated that one or more family members have been treated for cancer, $51 \%$ have been treated for heart disease, $52 \%$ have been treated for diabetes, and $56 \%$ have been treated for back or joint pain. The percentages were lower for Alzheimer's or dementia $(25 \%)$ and obesity $(27 \%) .{ }^{5}$ Descriptive statistics for the variables used in the model are reported by family group (Table 2). In general, the majority of respondents report a minimum of moderate exercise, and most respondent households contain at least one member on a special diet. ${ }^{6}$

\subsection{Estimation Results}

The parameters of the double-hurdle model in equations (2) and (3) were estimated using Stata/SE 13.1. Separate models were estimated for purchases at farmers' markets and at farm stands. The signs of significant parameter estimates in the probit model indicate the direction of the effect of their corresponding variables on a respondent's likelihood of buying foods at farmers' markets (Table 3) or farm stands (Table 4). For the Poisson model, the parameter estimates indicate how those variables influence the frequency of purchase at those local outlets.

\subsection{Farmers' Markets}

Of the six illnesses reported in our study, five (heart disease, diabetes, obesity, back/joint pain, and Alzheimer's disease/dementia) are not found to have a

5 In the U.S. population, $8.5 \%$ of adults have ever been diagnosed with cancer, $11.5 \%$ of adults have been diagnosed with heart disease, $9.3 \%$ of people in the United States have diabetes (diagnosed or undiagnosed), $13.9 \%$ of adults have osteoarthritis, $34.9 \%$ of adults are obese, and 5.3 million Americans currently have Alzheimer's disease (CDC, 2016).

6 In 2012, $3 \%$ of adults in the United States followed a special diet (examples given were Zone, vegan, and Ornish) as a complementary health approach (Peregoy et al., 2014). We asked not about specific diets, but about specific reasons for dieting. That, and the fact that our data are measured at the household level, may account for the discrepancy between the CDC statistic and our numbers. 
Table 2. Variable Definitions and Descriptive Statistics $(\mathrm{N}=4,706)$

\begin{tabular}{|c|c|c|}
\hline Variable & Mean & $\begin{array}{l}\text { Standard } \\
\text { Deviation }\end{array}$ \\
\hline \multicolumn{3}{|l|}{ Dependent variables } \\
\hline $\begin{array}{l}\text { Purchased at farmers' markets at least once within the past } \\
\text { month }\end{array}$ & 0.50 & 0.50 \\
\hline $\begin{array}{l}\text { Number of times food was purchased at farmers' markets in } \\
\text { past month }(0-50)\end{array}$ & 1.12 & 2.03 \\
\hline Purchased at farm stands at least once within the past month & 0.31 & 0.46 \\
\hline $\begin{array}{l}\text { Number of times food was purchased at farm stands in past } \\
\text { month }(0-25)\end{array}$ & 0.58 & 1.31 \\
\hline \multicolumn{3}{|l|}{ Health-related independent variables } \\
\hline Respondent, spouse, or child treated: cancer & 0.13 & 0.34 \\
\hline Sibling, parent, or grandparent treated: cancer & 0.48 & 0.50 \\
\hline Respondent, spouse, or child treated: heart disease & 0.11 & 0.31 \\
\hline Sibling, parent, or grandparent treated: heart disease & 0.47 & 0.50 \\
\hline Respondent, spouse, or child treated: diabetes & 0.16 & 0.37 \\
\hline Sibling, parent, or grandparent treated: diabetes & 0.43 & 0.50 \\
\hline Respondent, spouse, or child treated: obesity & 0.17 & 0.37 \\
\hline Sibling, parent, or grandparent treated: obesity & 0.17 & 0.38 \\
\hline Respondent, spouse, or child treated: joint pain & 0.38 & 0.49 \\
\hline Sibling, parent, or grandparent treated: joint pain & 0.33 & 0.47 \\
\hline Respondent, spouse, or child treated: Alzheimer's/dementia & 0.01 & 0.09 \\
\hline Sibling, parent, or grandparent treated: Alzheimer's/dementia & 0.24 & 0.43 \\
\hline Concerned about international food safety $(0-4)$ & 3.12 & 0.99 \\
\hline Exercise: equivalent of 1.5 - to 3 -mile walk per day & 0.42 & 0.49 \\
\hline Exercise: equivalent of 3+-mile walk per day & 0.12 & 0.32 \\
\hline Family member follows diet to treat illness & 0.30 & 0.46 \\
\hline Family member follows diet to keep fit & 0.53 & 0.50 \\
\hline Family member is vegetarian or vegan & 0.08 & 0.26 \\
\hline \multicolumn{3}{|l|}{ Other independent variables } \\
\hline Farmers’ markets within 5 miles & 0.66 & 0.47 \\
\hline Farm stands within 15 miles & 0.96 & 0.19 \\
\hline Cares about distance food travels & 0.37 & 0.48 \\
\hline Cares about pesticide residue on food & 0.74 & 0.44 \\
\hline Cares about price of food & 0.70 & 0.46 \\
\hline $\begin{array}{l}\text { Number of times respondent shops for food per month } \\
(0-9+)\end{array}$ & 6.31 & 5.31 \\
\hline Number of days respondent travels per month $(0-21+)$ & 8.18 & 3.87 \\
\hline $\begin{array}{l}\text { Number of correct answers on agricultural knowledge quiz } \\
(0-7)\end{array}$ & 2.37 & 1.58 \\
\hline Number of meals prepared at home per week (0-19+) & 12.94 & 4.41 \\
\hline Respondent is female & 0.52 & 0.50 \\
\hline Annual household income $(\$ 1,000$ s) $(10-500)$ & 71.13 & 61.24 \\
\hline Age $(18-108)$ & 47.94 & 16.01 \\
\hline Respondent has bachelor's degree & 0.55 & 0.50 \\
\hline Number of people in respondent's household $(0-14)$ & 2.57 & 1.28 \\
\hline Respondent is white & 0.69 & 0.46 \\
\hline Respondent is born in the United States & 0.89 & 0.32 \\
\hline
\end{tabular}

Note: Unless otherwise noted by a range in parentheses, each variable is a dummy variable. 
Table 3. Parameter Estimates of the Double-Hurdle Model for Farmers' Markets

\begin{tabular}{|c|c|c|c|c|c|c|}
\hline \multirow[b]{2}{*}{ Variable } & \multicolumn{3}{|c|}{ Probit $(\mathrm{N}=4,331)$} & \multicolumn{3}{|c|}{ Poisson $(\mathrm{N}=2,159)$} \\
\hline & Beta & $\begin{array}{l}\text { Standard } \\
\text { Error }\end{array}$ & $\begin{array}{l}\text { Marginal } \\
\text { Effect }\end{array}$ & Beta & $\begin{array}{l}\text { Standard } \\
\text { Error }\end{array}$ & $\begin{array}{l}\text { Marginal } \\
\text { Effect }\end{array}$ \\
\hline $\begin{array}{l}\text { Respondent, spouse, or child } \\
\text { treated: cancer }\end{array}$ & 0.00 & 0.06 & 0.00 & -0.02 & 0.05 & -0.04 \\
\hline $\begin{array}{l}\text { Sibling, parent, or grandparent } \\
\text { treated: cancer }\end{array}$ & $-0.12^{* * *}$ & 0.04 & $-0.05^{* * *}$ & $-0.13^{* * *}$ & 0.04 & $-0.24^{* * *}$ \\
\hline $\begin{array}{l}\text { Respondent, spouse, or child } \\
\text { treated: heart disease }\end{array}$ & 0.02 & 0.07 & 0.01 & 0.05 & 0.06 & 0.10 \\
\hline $\begin{array}{l}\text { Sibling, parent, or grandparent } \\
\text { treated: heart disease }\end{array}$ & 0.05 & 0.04 & 0.02 & $-0.09^{* *}$ & 0.04 & $-0.16^{* *}$ \\
\hline $\begin{array}{l}\text { Respondent, spouse, or child } \\
\text { treated: diabetes }\end{array}$ & 0.07 & 0.06 & 0.03 & 0.03 & 0.05 & 0.06 \\
\hline $\begin{array}{l}\text { Sibling, parent, or grandparent } \\
\text { treated: diabetes }\end{array}$ & -0.01 & 0.04 & 0.00 & 0.03 & 0.04 & 0.06 \\
\hline $\begin{array}{l}\text { Respondent, spouse, or child } \\
\text { treated: obesity }\end{array}$ & 0.03 & 0.06 & 0.01 & $0.16^{* * *}$ & 0.05 & $0.30^{* * *}$ \\
\hline $\begin{array}{l}\text { Sibling, parent, or grandparent } \\
\text { treated: obesity }\end{array}$ & 0.03 & 0.06 & 0.01 & $-0.14^{* * *}$ & 0.05 & $-0.27^{* * *}$ \\
\hline $\begin{array}{l}\text { Respondent, spouse, or child } \\
\text { treated: joint pain }\end{array}$ & 0.03 & 0.04 & 0.01 & $-0.12^{* * *}$ & 0.04 & $-0.23^{* * *}$ \\
\hline $\begin{array}{l}\text { Sibling, parent, or grandparent } \\
\text { treated: joint pain }\end{array}$ & 0.01 & 0.04 & 0.00 & $0.10^{* * *}$ & 0.04 & $0.20^{* * *}$ \\
\hline $\begin{array}{l}\text { Respondent, spouse, or child } \\
\text { treated: Alzheimer's/dementia }\end{array}$ & 0.29 & 0.21 & 0.12 & -0.15 & 0.18 & -0.29 \\
\hline $\begin{array}{l}\text { Sibling, parent, or grandparent } \\
\text { treated: Alzheimer's/dementia }\end{array}$ & 0.01 & 0.05 & 0.00 & 0.03 & 0.04 & 0.06 \\
\hline $\begin{array}{l}\text { Concerned about international } \\
\text { food safety }\end{array}$ & $0.06^{* * *}$ & 0.02 & $0.02^{* * *}$ & $0.08^{* * *}$ & 0.02 & $0.15^{* * *}$ \\
\hline $\begin{array}{l}\text { Exercises: equivalent of } 1.5 \text { - to } \\
3 \text {-mile walk per day }\end{array}$ & $0.26^{* * *}$ & 0.04 & $0.10^{* * *}$ & $0.36^{* * *}$ & 0.04 & $0.68^{* * *}$ \\
\hline $\begin{array}{l}\text { Exercises: equivalent of } 3+\text {-mile } \\
\text { walk per day }\end{array}$ & $0.21^{* * *}$ & 0.07 & $0.08^{* * *}$ & $0.31^{* * *}$ & 0.06 & $0.58^{* * *}$ \\
\hline $\begin{array}{l}\text { Family member follows diet to } \\
\text { treat illness }\end{array}$ & 0.07 & 0.05 & 0.03 & -0.01 & 0.04 & -0.02 \\
\hline $\begin{array}{l}\text { Family member follows diet to } \\
\text { keep fit }\end{array}$ & $0.11^{* *}$ & 0.04 & $0.04^{* *}$ & $0.12^{* * *}$ & 0.04 & $0.22^{* * *}$ \\
\hline $\begin{array}{l}\text { Family member is vegetarian or } \\
\text { vegan }\end{array}$ & $0.33^{* * *}$ & 0.08 & $0.13^{* * *}$ & -0.04 & 0.06 & -0.07 \\
\hline Farmers' markets within 5 miles & $0.08^{*}$ & 0.04 & $0.03^{*}$ & $0.10^{* * *}$ & 0.04 & $0.19^{* * *}$ \\
\hline Cares about distance food travels & $0.28^{* * *}$ & 0.04 & $0.11^{* * *}$ & $0.10^{* * *}$ & 0.04 & $0.19^{* * *}$ \\
\hline $\begin{array}{l}\text { Cares about pesticide residue on } \\
\text { food }\end{array}$ & $0.15^{* * *}$ & 0.05 & $0.06^{* * *}$ & 0.01 & 0.05 & 0.02 \\
\hline Cares about price of food & $-0.23^{* * *}$ & 0.04 & $-0.09^{* * *}$ & $-0.14^{* * *}$ & 0.04 & $-0.27^{* * *}$ \\
\hline $\begin{array}{l}\text { Number of times respondent } \\
\text { shops for food per month }\end{array}$ & $0.01^{* * *}$ & 0.00 & $0.00^{* * *}$ & $0.03^{* * *}$ & 0.00 & $0.06^{* * *}$ \\
\hline $\begin{array}{l}\text { Number of days respondent } \\
\text { travels per month }\end{array}$ & $0.02^{* * *}$ & 0.01 & $0.01^{* * *}$ & 0.01 & 0.00 & 0.01 \\
\hline
\end{tabular}


Table 3. Continued

\begin{tabular}{|c|c|c|c|c|c|c|}
\hline \multirow[b]{2}{*}{ Variable } & \multicolumn{3}{|c|}{ Probit $(\mathrm{N}=4,331)$} & \multicolumn{3}{|c|}{ Poisson $(\mathrm{N}=2,159)$} \\
\hline & Beta & $\begin{array}{l}\text { Standard } \\
\text { Error }\end{array}$ & $\begin{array}{l}\text { Marginal } \\
\text { Effect }\end{array}$ & Beta & $\begin{array}{l}\text { Standard } \\
\text { Error }\end{array}$ & $\begin{array}{l}\text { Marginal } \\
\text { Effect }\end{array}$ \\
\hline $\begin{array}{l}\text { Number of correct answers on } \\
\text { agricultural knowledge quiz }\end{array}$ & $0.04^{* * *}$ & 0.01 & $0.02^{* * *}$ & 0.02 & 0.01 & 0.03 \\
\hline $\begin{array}{l}\text { Number of meals prepared at } \\
\text { home per week }\end{array}$ & 0.01 & 0.00 & 0.00 & 0.01 & 0.00 & 0.01 \\
\hline Respondent is female & 0.04 & 0.04 & 0.02 & -0.01 & 0.04 & -0.02 \\
\hline $\begin{array}{l}\text { Annual household income } \\
\qquad \$ 1,000 \mathrm{~s})\end{array}$ & 0.00 & 0.00 & 0.00 & $0.00^{* * *}$ & 0.00 & $0.00^{* * *}$ \\
\hline Age & 0.00 & 0.00 & 0.00 & $0.01^{* * *}$ & 0.00 & $0.01^{* * *}$ \\
\hline Respondent has bachelor's degree & 0.00 & 0.04 & 0.00 & $0.09^{* *}$ & 0.04 & $0.16^{* *}$ \\
\hline $\begin{array}{l}\text { Number of people in respondent's } \\
\text { household }\end{array}$ & -0.01 & 0.02 & 0.00 & -0.02 & 0.02 & -0.03 \\
\hline Respondent is white & -0.05 & 0.05 & -0.02 & $-0.29^{* * *}$ & 0.04 & $-0.55^{* * *}$ \\
\hline $\begin{array}{l}\text { Respondent is born in the United } \\
\text { States }\end{array}$ & 0.01 & 0.06 & 0.00 & $0.11^{* *}$ & 0.06 & $0.21^{*}$ \\
\hline Constant & $-1.00^{* * *}$ & 0.15 & - & $-0.45^{* * *}$ & 0.15 & - \\
\hline Log likelihood & \multicolumn{3}{|c|}{$-2,846.48$} & \multicolumn{3}{|c|}{$-3,601.23$} \\
\hline
\end{tabular}

Notes: Asterisks $\left({ }^{*},{ }^{* *}\right.$, and $\left.{ }^{* * *}\right)$ indicate significance at the $10 \%, 5 \%$, and $1 \%$ levels, respectively. Standard errors for marginal effects suppressed because of space.

significant effect on the first decision of whether to buy foods at farmers' markets (Table 3). Reported occurrences of cancer in the respondent's family of procreation, however, negatively affect the likelihood of buying food at farmers' markets.

Disease incidences generally have a greater effect on the decision of how often to purchase at farmers' markets, given that one does so. Cancer, heart disease, or obesity among the respondent's siblings, parents, or grandparent decrease purchases at farmers' markets. Obesity among the respondent or his spouse or children increases purchases at a farmers' market. Joint pain affects the number of farmers' market purchases in different directions depending on whether the incidence is among the respondent, his spouse, or children, or among his siblings, parents, or grandparents. ${ }^{7}$

7 One reviewer wondered whether some diseases being significant when occurring outside the household but not when occurring within the household was because of few observations within the household. Roughly $10 \%-16 \%$ of respondents $(450-700)$ had a household member who was treated for cancer, heart disease, or diabetes, whereas $43 \%-49 \%$ had a nonhousehold family member who was treated. The percentages are about equal for family members within the household for obesity and back or joint pain, with $17 \%$ for obesity and $35 \%$ for back or joint pain outside the household. Less than $1 \%$ (about 38 people) had a household member who was treated for Alzheimer's or dementia, whereas $24 \%$ had a nonhousehold member who was treated. 
Table 4. Parameter Estimates of the Double-Hurdle Model for Farm Stands

\begin{tabular}{|c|c|c|c|c|c|c|}
\hline \multirow[b]{2}{*}{ Variable } & \multicolumn{3}{|c|}{ Probit $(\mathrm{N}=4,287)$} & \multicolumn{3}{|c|}{ Poisson $(\mathrm{N}=1,308)$} \\
\hline & Beta & $\begin{array}{l}\text { Standard } \\
\text { Error }\end{array}$ & $\begin{array}{l}\text { Marginal } \\
\text { Effect }\end{array}$ & Beta & $\begin{array}{l}\text { Standard } \\
\text { Error }\end{array}$ & $\begin{array}{l}\text { Marginal } \\
\text { Effect }\end{array}$ \\
\hline $\begin{array}{l}\text { Respondent, spouse, or child } \\
\text { treated: cancer }\end{array}$ & $0.17^{* * *}$ & 0.06 & $0.06^{* * *}$ & -0.07 & 0.07 & -0.10 \\
\hline $\begin{array}{l}\text { Sibling, parent, or grandparent } \\
\text { treated: cancer }\end{array}$ & 0.06 & 0.04 & 0.02 & $-0.13^{* *}$ & 0.06 & $-0.19^{* *}$ \\
\hline $\begin{array}{l}\text { Respondent, spouse, or child } \\
\text { treated: heart disease }\end{array}$ & 0.11 & 0.07 & 0.04 & -0.04 & 0.08 & -0.05 \\
\hline $\begin{array}{l}\text { Sibling, parent, or grandparent } \\
\text { treated: heart disease }\end{array}$ & 0.03 & 0.05 & 0.01 & $-0.12^{*}$ & 0.06 & $-0.16^{*}$ \\
\hline $\begin{array}{l}\text { Respondent, spouse, or child } \\
\text { treated: diabetes }\end{array}$ & $0.11^{*}$ & 0.06 & $0.04^{*}$ & 0.09 & 0.07 & 0.13 \\
\hline $\begin{array}{l}\text { Sibling, parent, or grandparent } \\
\text { treated: diabetes }\end{array}$ & -0.01 & 0.05 & 0.00 & $-0.17^{* * *}$ & 0.06 & $-0.24^{* * *}$ \\
\hline $\begin{array}{l}\text { Respondent, spouse, or child } \\
\text { treated: obesity }\end{array}$ & $0.10^{*}$ & 0.06 & $0.04^{*}$ & $-0.16^{* *}$ & 0.08 & $-0.22^{* *}$ \\
\hline $\begin{array}{l}\text { Sibling, parent, or grandparent } \\
\text { treated: obesity }\end{array}$ & $0.16^{* * *}$ & 0.06 & $0.06^{* * *}$ & $0.17^{* *}$ & 0.07 & $0.23^{* *}$ \\
\hline $\begin{array}{l}\text { Respondent, spouse, or child } \\
\text { treated: joint pain }\end{array}$ & $0.11^{* *}$ & 0.05 & $0.04^{* *}$ & -0.04 & 0.06 & -0.05 \\
\hline $\begin{array}{l}\text { Sibling, parent, or grandparent } \\
\text { treated: joint pain }\end{array}$ & -0.06 & 0.05 & -0.02 & $0.15^{* *}$ & 0.06 & $0.21^{* *}$ \\
\hline $\begin{array}{l}\text { Respondent, spouse, or child } \\
\text { treated: Alzheimer's/dementia }\end{array}$ & -0.02 & 0.21 & -0.01 & -0.03 & 0.24 & -0.04 \\
\hline $\begin{array}{l}\text { Sibling, parent, or grandparent } \\
\text { treated: Alzheimer's/dementia }\end{array}$ & -0.02 & 0.05 & -0.01 & 0.07 & 0.06 & 0.10 \\
\hline $\begin{array}{l}\text { Concerned about international } \\
\text { food safety }\end{array}$ & 0.03 & 0.02 & 0.01 & -0.01 & 0.03 & -0.02 \\
\hline $\begin{array}{l}\text { Exercises: equivalent of } 1.5 \text { - to } \\
3 \text {-mile walk per day }\end{array}$ & 0.05 & 0.05 & 0.02 & $0.15^{* *}$ & 0.06 & $0.20^{* *}$ \\
\hline $\begin{array}{l}\text { Exercises: equivalent of } 3+\text {-mile } \\
\text { walk per day }\end{array}$ & 0.07 & 0.07 & 0.02 & 0.14 & 0.10 & 0.20 \\
\hline $\begin{array}{l}\text { Family member follows diet to } \\
\text { treat illness }\end{array}$ & 0.04 & 0.05 & 0.02 & 0.07 & 0.07 & 0.09 \\
\hline $\begin{array}{l}\text { Family member follows diet to } \\
\text { keep fit }\end{array}$ & 0.04 & 0.05 & 0.01 & -0.03 & 0.06 & -0.04 \\
\hline $\begin{array}{l}\text { Family member is vegetarian or } \\
\text { vegan }\end{array}$ & 0.12 & 0.08 & 0.04 & -0.14 & 0.11 & -0.20 \\
\hline Farms stands within 15 miles & 0.00 & 0.11 & 0.00 & 0.04 & 0.15 & 0.06 \\
\hline Cares about distance food travels & $0.28^{* * *}$ & 0.04 & $0.10^{* * *}$ & $0.10^{*}$ & 0.06 & $0.15^{*}$ \\
\hline $\begin{array}{l}\text { Cares about pesticide residue on } \\
\text { food }\end{array}$ & -0.07 & 0.05 & -0.02 & $0.13^{* *}$ & 0.07 & $0.19^{*}$ \\
\hline Cares about price of food & $-0.17^{* * *}$ & 0.04 & $-0.06^{* * *}$ & $-0.16^{* * *}$ & 0.06 & $-0.23^{* * *}$ \\
\hline $\begin{array}{l}\text { Number of times respondent } \\
\text { shops for food per month }\end{array}$ & $0.01^{* * *}$ & 0.00 & $0.00^{* * *}$ & $0.02^{* * *}$ & 0.00 & $0.03^{* * *}$ \\
\hline $\begin{array}{l}\text { Number of days respondent } \\
\text { travels per month }\end{array}$ & $0.02^{* * *}$ & 0.01 & $0.01^{* * *}$ & 0.01 & 0.01 & 0.01 \\
\hline
\end{tabular}


Table 4. Continued

\begin{tabular}{|c|c|c|c|c|c|c|}
\hline \multirow[b]{2}{*}{ Variable } & \multicolumn{3}{|c|}{ Probit $(\mathrm{N}=4,287)$} & \multicolumn{3}{|c|}{ Poisson $(\mathrm{N}=1,308)$} \\
\hline & Beta & $\begin{array}{l}\text { Standard } \\
\text { Error }\end{array}$ & $\begin{array}{l}\text { Marginal } \\
\text { Effect }\end{array}$ & Beta & $\begin{array}{l}\text { Standard } \\
\text { Error }\end{array}$ & $\begin{array}{l}\text { Marginal } \\
\text { Effect }\end{array}$ \\
\hline $\begin{array}{l}\text { Number of correct answers on } \\
\text { agricultural knowledge quiz }\end{array}$ & $0.04^{* * *}$ & 0.01 & $0.01^{* * *}$ & $0.03^{* *}$ & 0.02 & 0.04 \\
\hline $\begin{array}{l}\text { Number of meals prepared at } \\
\text { home per week }\end{array}$ & 0.00 & 0.00 & 0.00 & 0.00 & 0.01 & 0.00 \\
\hline Respondent is female & 0.04 & 0.04 & 0.01 & -0.04 & 0.06 & -0.05 \\
\hline $\begin{array}{l}\text { Annual household income } \\
\qquad(\$ 1,000 \mathrm{~s})\end{array}$ & 0.00 & 0.00 & 0.00 & $0.00^{* *}$ & 0.00 & $0.00^{* *}$ \\
\hline Age & $0.01^{* * *}$ & 0.00 & $0.00^{* * *}$ & $0.01^{* * *}$ & 0.00 & $0.02^{* * *}$ \\
\hline Respondent has bachelor's degree & 0.04 & 0.04 & 0.01 & -0.06 & 0.06 & -0.09 \\
\hline $\begin{array}{l}\text { Number of people in respondent's } \\
\text { household }\end{array}$ & $0.06^{* * *}$ & 0.02 & $0.02^{* * *}$ & 0.02 & 0.02 & 0.03 \\
\hline Respondent is white & 0.07 & 0.05 & 0.02 & 0.00 & 0.07 & 0.00 \\
\hline $\begin{array}{l}\text { Respondent is born in the United } \\
\text { States }\end{array}$ & $0.25^{* * *}$ & 0.07 & $0.08^{* * *}$ & $0.50^{* * *}$ & 0.14 & $0.70^{* * *}$ \\
\hline Constant & $-1.89^{* * *}$ & 0.19 & - & $-1.01^{* * *}$ & 0.29 & - \\
\hline Log likelihood & \multicolumn{3}{|c|}{$-2,496.28$} & \multicolumn{3}{|c|}{$-1,801.02$} \\
\hline
\end{tabular}

Notes: Asterisks $\left({ }^{*},{ }^{* *}\right.$, and $\left.{ }^{* * *}\right)$ indicate significance at the $10 \%, 5 \%$, and $1 \%$ levels, respectively. Standard errors for marginal effects suppressed because of space.

Most other health-related variables that significantly affect either decision are found to have a positive effect. For example, those who are more concerned than friends or family about the safety of food grown outside of the United States are more likely to buy food from a farmers' market and to do so more frequently, consistent with the finding that some consumers believe other countries have less strict processing and chemical use regulations in agricultural foods (Loureiro and Umberger, 2005). Respondents who exercise the equivalent of at least 1.5 miles of walking each day are also more likely to purchase from and to purchase more often from farmers' markets. Vegetarians, vegans, or respondents who were following a special diet to stay fit were more likely to purchase food at farmers' markets.

The presence of a farmers' market within 5 miles of a respondent's zip code positively affects the likelihood and frequency of farmers' markets purchases, consistent with the intuition that a lower cost (both financial cost and time cost) of travel to the market would increase market purchases. Respondents who care about the distance their food travels from production location to purchase location are also more likely to buy at farmers' markets and to do so more frequently. This travel distance is generally shorter for farmers' markets than for traditional markets, and respondents may prefer a shorter distance for various reasons including that it reduces vehicle carbon emissions or that foods with shorter travel distance are believed to retain more nutrients (Lea, 2005). Similarly, respondents who care about the amount of pesticide residue on food 
are more likely to purchase at farmers' markets, which supports earlier findings that consumers are concerned about negative environmental or health impacts of pesticides (Sachs, Blair, and Richter, 1987). Respondents who are more concerned about food prices are less likely to buy food at farmers' markets, suggesting that price-sensitive consumers in our sample believe that farmers' market prices are higher relative to traditional outlets. Although the reaction of any given consumer to farmers' market prices may vary depending on several factors including the type and number of markets in her area and their offerings, the Project for Public Spaces and Columbia University (2013) found that $17 \%$ of respondents still considered price to be a barrier to shopping at farmers' markets. We also find that respondents who shop for food more frequently or travel more frequently are more likely to purchase food at farmers' markets. Consistent with Abello et al. (2014), ${ }^{8}$ demographic variables are generally found to be weak predictors of purchases at farmers' markets.

\subsection{Farm Stands}

Occurrences of cancer, diabetes, obesity, or joint pain among the respondent, her spouse, or children or incidences of obesity among any family member are found to increase the probability of purchasing foods from farm stands (Table 4). The frequency of purchases at farm stands is negatively affected by incidences of cancer, heart disease, or diabetes and positively affected by incidences of obesity or joint pain among the respondent's family of orientation. However, a negative effect on purchase frequency resulted when obesity was reported to occur in either the respondent or her spouse or children. As with farmers' markets, the effects of obesity incidence in the two family groups on purchases have the opposite direction from each other, but, strangely, across farmers' markets and farm stands the direction of the effects are opposite across family groups. In other words, although there is evidence that obesity incidence affects purchasing decisions, there is inconsistency of the effect across markets and across family groups.

Although many factors may come into play in this situation, a plausible explanation for this difference may be the operational and locational differences of the two types of markets. The recreational nature of farmers' markets is well documented in agrotourism literature (Farmer et al., 2011; Onyango, Govindsamy, and Alsup Egbers, 2015). In the case of obesity in the family of procreation, this recreational aspect, which frequently includes children's activities, may facilitate introducing more farmers' market purchases into the family's schedule, but not necessarily so for farm stands. New bonus programs offering extended benefits for fruit and vegetable purchases for households that are eligible for the Supplemental Nutrition Assistance Program (SNAP)

8 Although Abello et al. (2014) find that education level and certain age categories affect farmers' market visits, they find no relationship to income, sex, whether children live in the household, and older age categories. 
and Women, Infants, and Children Farmers' Market Nutrition Program (WICFMNP), such as the Double Dollars Program in Texas, may also offer additional incentives for a household to patronize a farmers' market. For example, through the WIC-FMNP, eligible pregnant and postpartum women and children up to 5 years of age can each receive up to $\$ 30$ in FMNP vouchers in addition to their regular WIC benefits. The value of these vouchers can then be further increased for purchases at markets supported by a bonus program. In contrast, although extended family members may benefit from additional incentives for farmers' markets purchases, they may value more highly features such as convenience and direct and focused interactions with a single vendor, which may be more easily facilitated at farm stands.

Incentive programs that encourage greater participation at both outlet types and across all family groups may be worthwhile initiatives for policy makers to implement. Such initiatives have been documented in the nutrition literature (McCormack et al., 2010; Payne et al., 2013) and are credited with enhancing health and profitability outcomes for consumers and producers, respectively. Additionally, a better understanding of the roles and influences on the family food buyer and the impact of joint decision making by household members on food purchases would serve to clarify direct-from-producer purchases at varying market outlets (Lackman and Lanasa, 1993).

Apart from self-reported illnesses, physical activity levels are significant in the second decision model. Respondents who consider themselves active (exercise equivalent to walking 1.5 miles to 3 miles a day or more) are likely to purchase more frequently at farm stands compared with those who consider themselves less active. Respondents who are concerned about the distance food travels from production location to purchase location are more likely to buy at farm stands, and those who care more about pesticide residue are likely to purchase more often at farm stands. Respondents who shop for food more frequently per month and travel more in a month are more likely to purchase foods at farm stands. Similarly to farmers' markets, more price-sensitive respondents are less likely to purchase from farm stands. In contrast to the findings of Zepeda and Li (2006) who found no effect of age on local food purchases, we find that respondents who are older are more likely to visit farm stands and likely to visit such stands more frequently. As with farmers' markets, those with a higher income purchase more frequently from farm stands. ${ }^{9}$

The number of markets, purchase decisions, health variables, and types of family members examined in this analysis make for a complex and nuanced story, and we summarize several main findings that hold generally in our study in Table 5. Because this is the first time many of these variables have been examined

9 Taylor and Villas-Boas (2016) find that low-income consumers are willing to pay more for access to more conventional food outlets (superstores and grocery stores) and relatively less for access to farmers' markets and may need to be incentivized to buy at farmers' markets. 
Table 5. Summary of Findings, Implications, and Future Research Opportunities Related to Understanding the Influence of Consumer Health Concerns on Direct-from-Producer Purchase Decisions

\begin{tabular}{|c|c|c|c|}
\hline General Finding & Possible Explanation & Implications & $\begin{array}{l}\text { Suggested Future Research } \\
\text { Direction }\end{array}$ \\
\hline $\begin{array}{l}\text { Disease incidences positively affect whether to } \\
\text { shop at farm stands but not at farmers' } \\
\text { markets. }\end{array}$ & $\begin{array}{l}\text { Preventing or treating disease } \\
\text { through diet takes effort. If a } \\
\text { household has a history of } \\
\text { disease incidence, this effort } \\
\text { may manifest itself more } \\
\text { visibly for farm stands, } \\
\text { which tend to be more } \\
\text { remotely located than } \\
\text { farmers' markets. }\end{array}$ & $\begin{array}{l}\text { Farmers' markets can attempt to meet } \\
\text { consumer demand of health-conscious } \\
\text { consumers by expanding services (e.g., } \\
\text { home delivery). }\end{array}$ & $\begin{array}{l}\text { Are there spatial and/or } \\
\text { geographic impacts on } \\
\text { market outlet selection-for } \\
\text { example, are farmers' } \\
\text { markets more accessible } \\
\text { than farm stands? } \\
\text { What strategies can be } \\
\text { adopted by direct market } \\
\text { growers to increase } \\
\text { attractiveness of offerings to } \\
\text { health-motivated buyers? }\end{array}$ \\
\hline $\begin{array}{l}\text { Direction of effect of family disease incidence on } \\
\text { frequency of farmers' market and farm stand } \\
\text { purchases varies by disease and by family } \\
\text { grouping. }\end{array}$ & $\begin{array}{l}\text { Diet is one way to address } \\
\text { disease. Other approaches to } \\
\text { manage health (e.g., dietary } \\
\text { supplements, therapy) may } \\
\text { partially displace household } \\
\text { efforts to address disease } \\
\text { through diet, depending on } \\
\text { the disease. }\end{array}$ & $\begin{array}{l}\text { Frequency of purchase has been shown to } \\
\text { increase product awareness and induce } \\
\text { price premiums. Thus, farmers' markets } \\
\text { and farm stands can focus efforts on } \\
\text { promotional tactics to increase regularity } \\
\text { of purchase for the disease/family group } \\
\text { represented by the buyer. A specific tactic } \\
\text { to increase buying frequency is loyalty } \\
\text { programs that emphasize repeat } \\
\text { purchases to increase usage rates and } \\
\text { overall revenues. }\end{array}$ & $\begin{array}{l}\text { Given time and budgetary } \\
\text { constraints, how do } \\
\text { consumers allocate resources } \\
\text { to address disease using } \\
\text { dietary approaches? } \\
\text { How do these resource } \\
\text { allocations differ by disease? }\end{array}$ \\
\hline $\begin{array}{l}\text { Selected health-related variables (concern for } \\
\text { food safety, food miles, pesticide residue, } \\
\text { special diet, and physical activity level) } \\
\text { positively affect whether to purchase from } \\
\text { farmers' markets and purchase frequency. } \\
\text { Several of these also have the same directional } \\
\text { effect for farm stand purchases. }\end{array}$ & $\begin{array}{l}\text { Consistent with findings in the } \\
\text { literature, health is a major } \\
\text { driver of food purchases and } \\
\text { of direct-from-grower } \\
\text { purchases specifically. }\end{array}$ & $\begin{array}{l}\text { Farmers' markets and farm stands can } \\
\text { invest in product offerings and } \\
\text { promotional strategies aimed toward } \\
\text { health-motivated consumers who are } \\
\text { influencing, deciding, or buying food } \\
\text { products for the household. }\end{array}$ & $\begin{array}{l}\text { How do other health-related } \\
\text { variables or alternative } \\
\text { definitions of the health } \\
\text { variables used in our study } \\
\text { affect food purchased } \\
\text { directly from growers? }\end{array}$ \\
\hline
\end{tabular}


in this context at this level of detail, we did not begin the study with ex ante hypotheses regarding these findings. Instead, we list possible explanations for these findings, possible implications for farmers and local-food market managers, and avenues for future research that would shed more light on these findings. We also note that, assuming that the marginal effects of the variables on purchase decisions are independent, they can be added to determine the cumulative effect of, for example, incidence of more than one disease in a household on the probability of a local-food market purchase or on the quantity of purchases.

\section{Conclusions}

Although existing studies have shown that general health motivations are a significant driver of local food purchases, our findings address current knowledge gaps by explicitly exploring the effects of specific diseases on purchases of food directly from producers. The positive association of the diseases with directfrom-producer food purchase in the first decision is consistent with the idea of perceived lower health risk of local foods often found in the literature. However, a negative effect on the frequency of purchases is revealed in some cases, given that at least one purchase is made. A possible explanation might be that diet is only one way to address (either through prevention or treatment) the family illnesses included in this study. Management of these illnesses may require more time to be devoted to other health-related activities, such as doctor visits, hospitalization, or physical therapy, which displace, among other things, food shopping events. Other variables examined (food safety concern, physical activity level, concerns about food miles and pesticide residue, and special diet) are found to increase both the likelihood of purchasing at farmers' markets and the frequency of purchases at farmers' markets, and several of these positively affect purchasing from farm stands.

Further research is recommended to explore what types of foods are purchased at farmers' markets and roadside stands, as offerings at these locations vary widely from fresh produce picked that morning to deep-fried pies containing locally grown apples and peaches, skewing the underlying assumption that these venues provide healthier food choices. Although our survey recorded the respondent's choice of food outlet, we did not capture exact food choices made at these or other outlets that feature locally sourced food and food productsretail or specialty grocers, community-supported agriculture shares, and so forth-in this study. As more and more traditional food stores expand their offerings of locally grown and healthier food options, additional survey efforts are needed to deepen our understanding of the connection between consumer health considerations, household composition, food choices, family roles and joint decision-making processes, and food purchased directly from producers.

Our study contributes to the existing literature that seeks to understand how consumers' current health situations and concerns may affect an individual's 
decision to purchase food directly from producers at either a farmers' market or a roadside stand. Findings are expected to provide those producers with improved awareness of the specific preferences underlying customer demand for their food offerings at direct market outlets. Producers are encouraged to emphasize the health benefits of their food products and explore customer incentives to encourage repeat purchase decisions. Moreover, marketing efforts and branding programs that allow producers to better demonstrate their understanding of the motivations and characteristics of consumers who seek out products sold by the grower may result in improved customer satisfaction, increased market share, and long-term profitability.

\section{References}

Abello, F.J., M.A. Palma, M.L. Waller, and D.P. Anderson. "Evaluating the Factors Influencing the Number of Visits to Farmers' Markets." Journal of Food Products Marketing 20,1(2014):17-35.

Berning, J.P. “Access to Local Agriculture and Weight Outcomes.” Agricultural and Resource Economics Review 41,1(2012):57-71.

Cameron, A.C., and P.K. Trivedi. Regression Analysis of Count Data. New York: Cambridge University Press, 1998.

Centers for Disease Control and Prevention. "Data and Statistics.” Internet site: http://www. cdc.gov/datastatistics/ (Accessed June 13, 2016).

Chen, S.N., J.F. Shogren, P.F. Orazem, and T.D. Crocker. "Prices and Health: Identifying the Effects of Nutrition, Exercise, and Medication Choices on Blood Pressure." American Journal of Agricultural Economics 84,4(2002):990-1002.

Conner, D.S., and R. Levine. "Circles of Association: The Connections of Community-Based Food Systems." Journal of Hunger and Environmental Nutrition 1,3(2007):5-25.

Cox, C.L. "An Interaction Model of Client Health Behavior: Theoretical Prescription for Nursing." Advances in Nursing Science 5,1(1982):41-56.

Darian, J.C., and L. Tucci. "Perceived Health Benefits and Food Purchasing Decisions." Journal of Consumer Marketing 28,6(2011):421-28.

Engel, J.F., R.D. Blackwell, and P.W. Miniard. Consumer Behavior. Chicago: Dryden Press, 1990.

Farmer, J.R., C. Chancellor, A. Gooding, D. Shubowitz, and A. Bryant. “A Tale of Four Farmers Markets: Recreation and Leisure as a Catalyst for Sustainability." Journal of Park and Recreation Administration 29,3(2011):11-23.

Food and Marketing Institute. "Prevention Magazine and Food Marketing Institute Release 21st Annual 'Shopping for Health' Survey Results.” June 25, 2013. Internet site: http: //www.fmi.org/news-room/latest-news/view/2013/06/25/prevention-magazine-andfood-marketing-institute-release-21st-annual-shopping-for-health-survey-results (Accessed April 29, 2014).

Gao, X.M., E.J. Wailes, and G.L. Cramer. "Double-Hurdle Model with Bivariate Normal Errors: An Application to U.S. Rice Demand.” Journal of Agricultural and Applied Economics 27,2(1995):363-76.

Govindasamy, R., J. Italia, and C. Liptak. "Quality of Agricultural Produce: Consumer Preferences and Perceptions.” P Series No. 36739, New Brunswick, NJ: Department of Agricultural, Food, and Resource Economics, Rutgers University, 1997. 
Greene, W.H. Econometric Analysis. 6th ed. Upper Saddle River, NJ: Prentice Hall, 2008.

Lackman, C., and J.M. Lanasa. "Family Decision-Making Theory: An Overview and Assessment." Psychology and Marketing 10,2(1993):81-93.

Lea, E. "Food, Health, the Environment and Consumers' Dietary Choices." Nutrition and Dietetics 62,1(2005):21-25.

LocalHarvest Inc. "Farm Stands." Internet site: http://www.localharvest.org/search.jsp? \&ty= 10 (Accessed April 10, 2014).

Loureiro, M.L., and W.J. Umberger. "Assessing Consumer Preferences for Country-of-Origin Labeling.” Journal of Agricultural and Applied Economics 37,1(2005):49-63.

Maples, M., K.L. Morgan, M.G. Interis, and A. Harri. "Who Buys Food Directly from Producers in the Southeastern United States?" Journal of Agricultural and Applied Economics 45,3(2013):509-18.

Martinez, S., M. Hand, M. Da Pra, S. Pollack, K. Ralston, T. Smith, S. Vogel, et al. Local Food Systems: Concepts, Impacts, and Issues. Washington, DC: U.S. Department of Agriculture, Economic Research Service, Economic Research Report No. 97, 2010.

McCormack, L.A., M.N. Laska, N.I. Larson, and M. Story. "Review of the Nutritional Implications of Farmers' Markets and Community Gardens: A Call for Evaluation and Research Efforts." Journal of the American Dietetic Association 110,3(2010): 399-408.

McDowell, A. "From the Help Desk: Hurdle Models." Stata Journal 3,2(2003):178-84.

McFadden, D. "Conditional Logit Analysis of Qualitative Choice Behavior." Frontiers in Econometrics. P. Zarembka, ed. New York: Academic Press, 1974, pp. 105-42.

. "What Do We Mean by 'Local Foods'?” Choices 30,1(2015):1-6.

McFadden, D.T., and S.A. Low. "Will Local Foods Influence American Diets?” Choices 27,1(2012):1-7.

Meyerhoefer, C.D., and E.S. Leibtag. "A Spoonful of Sugar Helps the Medicine Go Down: The Relationship between Food Prices and Medical Expenditures on Diabetes." American Journal of Agricultural Economics 92,5(2010):1271-82.

Moore, E.S., W.L. Wilke, and R.J. Lutz. "Passing the Torch: Intergenerational Influences as a Source of Brand Equity." Journal of Marketing 66,2(2002): 17-37.

Nayga, R.M., Jr., D. Lipinski, and N. Savur. “Consumers' Use of Nutritional Labels while Food Shopping and at Home." Journal of Consumer Affairs 32,1(1998):106-20.

Newey, W.K. "Efficient Estimation of Limited Dependent Variable Models with Endogenous Explanatory Variables.” Journal of Econometrics 36,3(1987):231-50.

Onozaka, Y., G. Nurse, and D.T. McFadden. "Defining Sustainable Food Market Segments: Do Motivations and Values Vary by Shopping Locale?” American Journal of Agricultural Economics 93,2(2010):583-89.

Onyango, B., R. Govindsamy, and R. Alsup Egbers. "Uncovering Success Attributes for Direct Farmers' Markets and Agri-Tourism in the Mid-Atlantic Region of the United States." International Food and Agribusiness Management Review 18,2(2015):63-78.

Palan, K.M. and R.E. Wilkes. "Adolescent-Parent Interaction in Family Decision Making." Journal of Consumer Research 24,2(1997):159-69.

Payne, G., H. Wethington, L. Olsho, J. Jernigan, R. Farris, and D. Klein Walker. “Implementing a Farmers' Market Incentive Program: Perspectives on the New York City Health Bucks Program." Preventing Chronic Disease 10(August 2013):1-9.

Peregoy, J.A., T.C. Clarke, L.I. Jones, B.J. Stussman, and R.L. Nahin. Regional Variation in Use of Complementary Health Approaches by U.S. Adults. Hyattsville, MD: National Center for Health Statistics (NCHS), NCHS Data Brief No. 146, 2014. Internet site: http://www.cdc.gov/nchs/data/databriefs/db146.pdf (Accessed October 2016). 
Project for Public Spaces and Columbia University. Farmers Markets as a Strategy to Improve Access to Healthy Food for Low-Income Families and Communities. New York: Project for Public Spaces, 2013. Internet site: http://www.pps.org/wp-content/uploads/2013/02/ RWJF-Report.pdf (Accessed October 2016).

Sachs, C., D. Blair, and C. Richter. "Consumer Pesticide Concerns: A 1965 and 1984 Comparison." Journal of Consumer Affairs 21,1(1987):96-107.

Salois, M.J. "Obesity and Diabetes, the Built Environment, and the 'Local' Food Economy in the United States, 2007.” Economics \& Human Biology 10,1(2012):35-42.

Schneider, M.L., and C.A. Francis. "Marketing Locally Produced Foods: Consumer and Farmer Opinions in Washington County, Nebraska." Renewable Agriculture and Food Systems 20,4(2005):252-60.

Shepherd, C.D., and R.B. Woodruff. "A Muddling through Model of Family Purchase Conflict Management." Proceedings of the Society for Consumer Psychology: Annual Convention of the American Psychological Association. Nashville, TN: Society for Consumer Psychology, 1988, pp. 73-86.

Taylor, R., and S.B. Villas-Boas. "Food Store Choices of Poor Households: A Discrete Choice Analysis of the National Household Food Acquisition and Purchase Survey (FoodAPS)." American Journal of Agricultural Economics 98,2(2016):513-32.

Thilmany, D., C.A. Bond, and J.K. Bond. "Going Local: Exploring Consumer Behavior and Motivations for Direct Food Purchases." American Journal of Agricultural Economics 90,5(2008):1303-1309.

Thompson, E., Jr., A.M. Harper, and S. Kraus. Think Globally-Eat Locally. San Francisco: American Farmland Trust, San Francisco Foodshed Assessment, 2008.

U.S. Department of Agriculture, Agricultural Marketing Service. "Farmers Markets Directory Search.” Internet site: http://search.ams.usda.gov/farmersmarkets/ (Accessed April 8, 2014).

U.S. Department of Health and Human Services (USDHHS). "Prevention Makes Common 'Cents.” 2003. Internet site: http://aspe.hhs.gov/health/prevention/ (Accessed June 3, 2015).

Vermeir, I., and W. Verbeke. "Sustainable Food Consumption: Exploring the Consumer 'Attitude-Behavioral Intention' Gap." Journal of Agricultural and Environmental Ethics 19,2(2006):169-94.

Vogt, R.A., and L.L. Kaiser. "Still a Time to Act: A Review of Institutional Marketing of Regionally-Grown Food." Agricultural and Human Values 25,2(2008):241-55.

Wolf, M.M., A. Spittler, and J. Ahern. "A Profile of Farmers' Market Consumers and the Perceived Advantages of Produce Sold at Farmers' Markets.” Journal of Food Distribution Research 36,1(2005):192-201.

Wooldridge, J.M. Econometric Analysis of Cross Section and Panel Data. Cambridge, MA: MIT Press, 2010.

World Health Organization (WHO). Diet, Nutrition and the Prevention of Chronic Diseases: Report of a Joint WHO/FAO Expert Consultation. Geneva: WHO, Technical Report Series 916, 2003.

Zepeda, L., and C. Leviten-Reid. "Consumers' Views on Local Food.” Journal of Food Distribution Research. 35,3(2004):1-6.

Zepeda, L., and J. Li. "Who Buys Local Food?" Journal of Food Distribution Research. 37,3(2006):1-11. 